\title{
BETWEEN THE MEMORY OF HERITAGE AND THE HERITAGE OF MEMORY. THE SEARCH FOR CONCEPTUAL SIMILARITIES
}

Wojciech WRZOSEK

\section{ABSTRACT}

This paper introduces into the topic of memory and heritage, history and culture. Each of these four categories can be used to organise this topic, remaining within a system of necessary dependence.

\section{KEYWORDS:}


We have seen the fertility of this compilation on our subject demonstrated, both rhetorically and factually. It enabled us to show mutual entanglements and the authors of these studies and research to freely choose both the empirical domain and their take on the issue. Between us, both variants of the coupled notions are able to contain the large issues associated with the capacity of the heritage notion and the range of modern humanist associations of the term memory. We should also stress that, in the recent decades, the term memory became separated from the common field of associations with the individualistic and biologicist roots of its semantics almost as successfully as the term social organism, hardly associated with a biological one. Today memory with an additional modifier, e.g., historical, heritage, etc., no longer makes us think of the neuro-physiological or cognitive structures of individual memory. Even more so, the term memory, memoire, or memoria - thanks to IT metaphors as well - is not tied to its associations with individual either. Halbwachs' daring sociologising (or perhaps psychologising in the spirit of social psychology) notional movement has been domesticated wo that the ideas of collective, social, and recently proposed cultural memory, or even memory of culture, hold no surprises. It does not lead us neither to its neurophysiological nor individualist understanding.

The proof is that our authors who use the term memory internalised it long ago. While those who do not use it know that, in our world conceptualisation resources, the idea of memory is not exclusively related to the ability to retain it, i.e., individual memory.

There are so many dimensions to the studies of memory that they do not belong to any single discipline of humanities or social studies, yet may belong to many. It all depends on a conceptual act and the network of categories which operationalise it. Also, just like the notion of culture produced culturology or culture studies 1 , the notion of memory begot memory studies. ${ }^{2}$

This is due to the fact that the idea of memory, similarly to that of culture, is broadly defined. The first one who broadened the term memory was Maurice Halbwachs. It is thus crucial for the modern research inspired by the French sociologist's solution is the acceptance of the supra-individual status of collective memory and, consequently, its non-psycho-biological nature. ${ }^{3}$ The classic approaches to the issue of memory were remembered much later, like the sociological studies of the French

'Yuri Lotman's studies on the theory of memory and culture, which supposedly inspired the classic works of Jan Assmann, are a separate tradition.

${ }^{2}$ History and Memory and the Centre for the Study of Historical Consciousness confirm this trend.

${ }^{3}$ Halbwachs M., La mémoire collective, Paris 1950; idem, Les cadres sociaux de la mémoire, Paris; La topographie légendaire des évangiles en terre sainte. Étude de mémoire collective. Paris 1941. 
researcher, historian and theoretician of art, Aby Warburg. Many modern clasics of memory studies refer to that very approach, such as the studies into mentality inspired by Emil Durkheim's school. It may be said thus that the famous research of Pierre Nora continue them. ${ }^{4}$

Much has been written on Nora's work. His model studies serve as a conceptual alibi for almost everyone who has ever but touched the issues of memory, historical memory in particular. In German research, the classic in the field is Jan Assmann. ${ }^{5}$ Who, as he says himself, refers to Aby Warburg amd Yuri Lotman. ${ }^{6}$ Whereas here we can observe the already mentioned connection between memory and culture. It is a separate trend in memory studies, which approach the history of memory only at a deeper analytical level.

We used the expression 'hoary building of culture'. Not by accident. We discussed the synchronic organisation of culture. Still, it should be stressed, that we always understand culture as preserving past experience. Moreover, one of the most important definitions characterises culture as the 'non-genetic' collective memory. Culture is memory. Therefore, it is always bound to history, always means the continuity of the axiological, intellectual, and spiritual life of a human, society, and mankind. For this reason, when we speak about our, modern culture, we may not even suspect we are talking about the long road it has travelled. This road is counted in millennia, crosses the boundaries of histoirical epochs, national cultures, and plunges us into a single one, the culture of humanity?

This approach which organises Assmann's reflection on cultural memory was apparently inherited from Lotman. The terms memory of culture and cultural memory which cover modern research into historical memory lead to the permeation of a new

\footnotetext{
${ }^{4}$ Nora P., "La mémoire collective", in: La Nouvelle Histoire, dir. Par. R. Chartier, J. Le Goff, J. Revel, Paris 1978, p. 398; Le Goff, Storia e memoria, Einaudi 1977.

${ }^{5}$ Assman J., Das kulturelle Gedächtnis. Schrift, Erinnerung und politische Identität in den frühen Hochkulturen, München 1992.

${ }^{6}$ Assmann J.: Pamięć kulturowa: Pismo, zapamiętywanie i polityka tożsamości w cywilizacjach starożytnych [Cultural memory], Warszawa 2008, p. 169; Lotman J.,Uspienskij B., "Die Rolle Dualistischer Modelle in der Dynamic der russischen Kultur (bis zum Ende des 18 Jahrhunderts)”, Poetica 9, p. 1-40; Аотман Ю, Память, Чему учатся мюди. Статьи и заметки, Москва 2010, р. 249-270.

${ }^{7}$ Мы употребили выражение «вековое здание культуры». Оно не случайно. Мы говорили о синхронной организации культуры. Но сразу же надо подчеркнуть, что культура всегАа подоразумевает сохранение предшествующего опыта. Более того, одно из важнейших определений культуры характеризует ее как «негенетическую» память комлектива. Кумьтура есть память. Поэтому она всегда связана с историей, всегда подразумевает непрерывность нравственной, интелектуальной, духовой жизни человека, общества и человечества. И потому, когАа мы говорим о культуре нашей, современной, мы, может быть сами того не подезревая, говорим о огромном пути, который эта культура прошиа. Путь этот насчитывает тысячелетия, перешагивает границы исторических эпох, национальных культур и погружает нас в одну культуру - культуру человечества Аотман Ю, Беседы о русской культуре. Быт и традиции русского Аворянства (XVIII - начало XIX века), Санкт-Петербург - СПБ 1994, p. 8.
} 
problem field to historical research, namely, the culturological (culture-scientific) problematisation of issues.

Whether we want it or not, the connection of the supra-individual semantic field of collective memory with history or cultural anthropology, or, more precisely, historical anthropology, or theory of culture leads us to the research domain defined as cultural memory or memory of culture.

In the topic of memory studies - and not only here - it is most important to adopt a conceptualisation perspective. It determines the research status of the studied item/object. For instance, one of the forms of modern research into the past collective memory are studies into the reception of elite memory by common memory, postulated by the research on the past historical culture. The essence of collective memory, the present state of imaginations of the past, lies in this collective memory, general opinions on the past. According to the researchers in this field, the state of the common imaginarium of the past is more important for historical culture than which visions of the past were suggested for all by the "opinion-making centres" of a given culture. Therefore, this topic comprises not only the elite and official knowledge about the past codified by historians and their patrons (e.g., monarchs, states) but also the prevailing beliefs; spontaneously formed convictions about the past are sometimes far remote from "professional historiography" but instead close to the collective memory flowing from the specific historical culture of a given society. Historical culture, which is the world of reflection-less thought habits or institutionalised socialisation (education), is responsible for the mechanisms of structuralisation of memory to a greater extent than other components of culture. ${ }^{8}$

Already in the times of our research experience, the times of the research team "Historical consciousness of Poles" directed by Jerzy Topolski and Andrzej Feliks Grabski, we knew that the approach to the topic of historical consciousness virtually depends on the researcher's subjective perspective depending on his/her competence. Both the co-author of the global methodology of history and the legendary expert in general and Polish historiography believed the subjective conceptualisation of the issues of historical consciousness to be acceptable. Wheras they sympathised themselves with the socioligising understanding of social consciousness, of which historical consciousness was a part.

${ }^{8}$ Rüsen J., Geschichtskultur als Forschungsproblem, Historische Orientierung, Köln, 1992; Woolf D., The Social Circulation of the Past: English Historical Culture 1500-1730, Oxford, 2003. 
We can admit that this term remains a convenient umbrella to this day. It contains all our research activities related to the heritage of memory/memory of heritage.

Obviously, our studies bear the traces of reflection upon memory and heritage accumulated over thirty years. Memory studies grew to become a separate field of study. Memoiristics is a serious name for a sub-discipline which does not focus on memoirs in the least. Our studies partake in all traditions. They represent diversity in both empirical and theoretical sense. Still, in both senses, they are a kind of case studies. Some are more historical while others tap the tradition of ethnographic thought, or even anthropology of modern culture. Historical studies prevail, however, and I do not describe them so simply because they use historical data as empirical material. They are historical because, in their narrative character, they put forward historical argumentation and persuasion.

\section{TRANSLATION: Andrzej PIETKIEWICZ}

BIBLIOGRAPHY:

Assman J., Das kulturelle Gedächtnis. Schrift, Erinnerung und politische Identität in den frühen Hochkulturen, München, 1992.

Assmann J., Pamięć kulturowa: Pismo, zapamiętywanie i polityka tożsamości w cywilizacjach starożytnych, Warszawa, 2008.

Halbwachs M., La mémoire collective, Paris, 1950.

Halbwachs M., Les cadres sociaux de la mémoire, 1925, Paris.

Halbwachs M., La topographie légendaire des évangiles en terre sainte. Étude de mémoire collective, Paris 1941. Le Goff J., Storia e memoria, Torino, 1977.

Lotman J., Uspienskij B., Die Rolle Dualistischer Modelle in der Dynamic der russischen Kultur (bis zum Ende des 18 Jahrhunderts), „Poetica”, 1977, nr 9, s. 1-40.

Nora P., La mémoire collective, [w: ] La Nouvelle Histoire, red. R. Chartier, J. Le Goff, J. Revel, Paris, 1978. Rüsen J., Historische Orientierung, Köln, 1994.

Woolf D., The Social Circulation of the Past: English Historical Culture 1500-1730, Oxford, 2003.

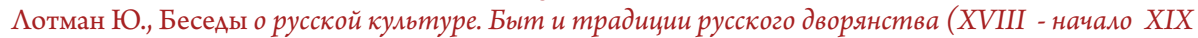
века), Санкт-Петербург, 1994.

Аотман Ю., Память, Чему учатся мюАи. Статьи и заметки, Москва, 2010. 